\title{
Staying young today: Vito Mancuso's Hegelian theology through the lens of Vasil Gluchman's ethics of social consequences
}

\author{
Corneliu C. Simut
}

\begin{abstract}
This paper is an attempt to present the Hegelian theology of Vito Mancuso, a radical lay Catholic theologian, from the perspective of the ethics of social consequences, as primarily promoted by Vasil Gluchman. Mancuso is a keen observer of today's society and he identifies a serious flaw among contemporary people in what he calls the idol of our time. This so-called idol is a human desire which seems to have been promoted more aggressively within contemporary society through various publicity channels, so it has developed into a mass phenomenon in today's world. According to Mancuso, this desire is man's longing to stay young despite the natural process of aging, a fact which has individual, spiritual, as well as social implications. He also introduces the necessity for the cultivation of one's soul for the personal benefit of individuals but also for the prosperity of society in general. In other words, Mancuso borrows, from Hegel, the necessity that the human spirit should develop to the point of positively accepting the materiality of its natural constitution for the wellbeing of all individuals living in the same society which very much resembles Gluchman's focus on human reasoning and moral action aimed at the promotion of positive consequences and moral duty as means to educate the human spirit towards tolerance and responsibility, all key concepts in Gluchman's ethics of social consequences.
\end{abstract}

Keywords: youth, value, dignity, humanity, education

\section{Introduction}

Vito Mancuso is a famous Italian lay Catholic theologian who - having renounced his priestly vows as well as his ecclesiastical ordination - has been, for the past two decades, actively involved in promoting a non-traditional understanding of Christian doctrine from the perspective of Hegel's philosophy and the idea that the spirit is material. A married man and father of two; Mancuso is a prolific writer who has produced well over ten books which have enjoyed enormous public success; for instance, his book L'anima et il suo destino (The Soul and Its Destiny, 2007) has sold over two hundred thousand copies which, by any standards whatsoever, is a remarkable feat for a theological book. In his entire output - books, articles, newspaper columns, and interviews on TV, radio, and online - Mancuso seeks to address fundamental issues of the human being such as the meaning of life and death as well as how these human realities are perceived by men and women living today mostly in Western European societies which are characterized by scientific development, social progress, and cultural diversity.

Contemporary people, Mancuso believes, face a rather serious problem which most of them seem to be unaware of, and some live as if they were completely ignorant regarding this particular aspect (Simut, 2011, pp. 105-110). This problem, which Mancuso details in a thorough analysis with evident ethical consequences, has to do with man's desire to be forever young. To be clear about it and also in order to highlight the gravity of the issue, Mancuso makes it plain that youth is the idol of our time. This human desire is assessed in Mancuso's thought from the perspective of the ethics of social consequences, which is concerned with a significant range of vital concepts revolving around the idea of humanity, a core concept within the ethics of social consequences of Vasil Gluchman's conception (Gluchman, 2006, p. 6 ). Thus, humanity is respect for as well as the pursuit of human dignity, an anthropological reality which is attached to the human being by birth, 
and which can be enhanced by achievement of or by the conscientious effort to do good (Rae, 2000, p. 37).

As far as the human being is concerned, this is defined by human life and the effort to preserve human life, which also qualifies the human being as a moral agent. In its capacity as moral agent, the human being is characterized by moral reasoning and moral action (Gluchman, 2007, pp. 161-162). When it comes to the actions of the human being, the ethics of social consequences presents us with a duality: right actions and moral actions, which although different in some respects-share a concern for the prevalence of positive consequences that support humanity in general. This can be achieved if people realize that they need to cultivate and then implement principles like tolerance, responsibility, and justice out of a profound feeling of moral duty, which is embedded in the human being (Gluchman, 2003, pp. 7-19).

Resuming Mancuso's thought and his evaluation of today's society, everybody wants to be young and for Mancuso this is a serious problem mostly because, due to his Hegelian understanding of theology which focuses on the idea of spirit as a material reality, the desire to stay young is neither natural to nor beneficial for the human being. There is also an explanation for such a desire which is shared by the vast majority of today's men and women, and this has to do - at least in Mancuso's perception - with the fact that spirituality was taken over by material concerns. Mancuso actually explains that the primacy of the spirit was lost in favor of the body, which is nothing but the decline of the spiritual dimension of humanity in favor of the material dimension. Before delving, however, into an analysis of this particular reality, Mancuso takes some time to explain how the young human exists and behaves within the world and how this reality generates the desire to stay young in people who go through the process of aging.

\section{From the reality of youth to the desire to stay young}

According to Mancuso, the young person is factually identified with his or her body to the point that he or she is indeed his or her own body (Mancuso, 2008, p. 239). This identification between the young person and his body is meant to highlight the status of his soul and, in Mancuso's view, the soul of the young exists in a state of underdevelopment (Kerem, 1999, p. 73). To come closer to Mancuso's exact depiction, the soul of the young is unripe, very much like a green fruit which has not yet become mature. The lack of maturity in a young person is not a problem in itself but it does point to the fact that the young do not have a fully developed consciousness. This renders their soul naive, unilateral, and lacking the wisdom of life. Mancuso takes the description a little further by saying that the soul of the young is primarily vegetative and animalistic in nature.

There is, however, a concession that Mancuso makes with regard to the nature of the young soul, in the sense that this can also be candid or pure, even childlike, but this state of affairs does not last forever. The purity of the young soul is not there to stay for good unless the soul itself blooms into maturity. If this necessary step is not taken, then the soul of the young will never reach wisdom. But in order for wisdom to be achieved, the young soul must go through life and even experience pain. In Mancuso, experience and pain seem to lead the young soul towards life experience which in turn brings forth much needed spiritual maturity. To use Mancuso's own rendering, the human soul needs a master whose duty is to help it develop, and the grand master of the human soul is life itself. Life's duty is to mold the soul and the human person would better let life do its job if he or she really wants to grow in maturity. It is equally true that being a grown up person is not an easy thing; when life molds the soul, suffering is unavoidable but it is through suffering that life chooses to shape the soul and make it grow in such a way that it develops its spiritual side (Mancuso, 2008, p. 239). 
This discussion about young people is vital to Mancuso's argument because the life philosophy of youngsters proves to be a treatise on today's society primarily because of its poignant desire to be and stay young in all respects. In order to complete his picture about the way young people think and behave, Mancuso resorts to some of Blaise Pascal's thoughts about the young, especially the fact that they do not judge well (Pascal, 1995, p. 13). Thus, the young are pictured as immersed in entertainment, noisy activities, and concerns about the future; this image, however, is applied by Mancuso to contemporary society. People nowadays seem to be incapable of looking beyond entertainment and how their lives will develop in future. The world seduces almost everybody with its shiny things, and this is everything people tend to see: things. There is less concern about those realities which are not things, such as morality and thinking. If people, regardless of their actual age, think and behave like youngsters, the preoccupation for things will be dominant to the detriment of ethical values which confer spirituality to human life. Contemporary society suffers from an accelerated decline of morality and especially of moral reasoning as well as moral action (Turiel, 2002, p. 33).

As there is almost no concern for the soul and its matters, today's people have weak souls and this reality reflects itself in the world. The soul of people belonging to contemporary society is literally conquered by materialism, so the thinking and actions of today's people is likely to produce fewer and fewer right actions. The situation is bad enough if this image of today's society is applied to individuals, and it reaches an alarming level of global gravity when it fits the lives of most people living nowadays. Mancuso's concern has to do not only with the reality of today's spiritual scarcity as manifested in the lives and actions of today's people, but also with the entertainment industry which fosters the fuel for the denigration of spirituality and the enhancement of savage materialism. This situation has a powerful impact on today's social ethics in the sense that there is nothing left in the lives of contemporary individuals provided entertainment is somehow cut off from their daily activities. Without entertainment, today's society - and, of course, its members - is rendered dry and full of boredom. This is the moment, however, from whence the personal and communitarian perception of nothingness can be seen clearly (Mancuso, 2008, p. 239). On the other hand, it is the starting point of a form of ethics which can influence society for the better, with practical results in moral reasoning and acting but also in producing a sense of responsibility with present as well as future implications (Stone, 2001, p. 56).

Mancuso is not very happy with the present condition of today's society and he quite bitterly decries the strange - and sometimes even hilarious - attitudes of people who want to look younger in order to fit more or less the trend of the entire society. To give just some examples, Mancuso expresses his strong disapproval of the fact that everything within society moves around young people and elderly persons try their best to look or behave like youngsters. Thus, Mancuso points out that older women dress like little girls while men with white hair force themselves into talking like teenagers. This state of affairs appears to be highly disturbing for Mancuso, who cannot refrain from noticing that elderly people were caught by some sort of frantic desire to have fun, entertain themselves, and even think about the future as if they were adolescents (Booth, 1994, p. 40).

He knows something is deeply wrong here, not only at social level but also with respect to ethics and morality in general. Ethical and moral values have been drastically changed because ideas such as moral duty and responsibility are quite hard to find in people who only live for entertainment. It is impossible to say for a fact whether Mancuso is indeed (being) sarcastic but he definitely sounds like that when he writes that everybody in today's society elderly people included - live only for the weekend and for holidays. At the end of the day, it is a frightening view for Mancuso because this particular life style, which is in constant demand of entertainment and teenage fun, shows that today's society cannot stop from this 
downward spiral but can feel - in a scary way - its sheer nothingness and worthlessness (Pryke, 2006, p. 29).

Mancuso seems pretty convinced that never before has society fallen so low, a reality which is described as "shameful futility". This is why he is painfully aware of the ethical implications of such a debased approach to life, which seems to have engulfed everything and everybody. The real problem here is ethics, and Mancuso knows this because he points out that the elderly have lost their wisdom but also their "inestimable value". According to Mancuso, they actually forgot that their wisdom-which is given or should have been given by their experience of life - was much more important and indeed superior to what he calls "the animalistic vitality of the young" (Mancuso, 2008, p. 240).

It has to be said here that Mancuso identified the real issue at stake, namely the problem of value which has practical consequences throughout society as a whole. When one's own value is forgotten, the human being in its entirety suffers from a demeaning reduction of its selfapprehension. The appreciation of human life is not properly assessed and human dignity achieved either by birth of by personal effort - loses its most fundamental meaning in correctly evaluating man's being both for himself and other individuals. Therefore, humanity in general is fatally flawed as the respect for, as well as the pursuit of, human dignity are irremediably damaged (Friel \& Friel, 1988, pp. 114-116).

This transforms human beings into victims. Youngsters and especially elderly adults are victims of an idea which pushes everybody to desire immaturity, decadence, and deviance. It is only natural for people to become old and, while doing so, also to grow in wisdom, value, and morality. Consumer society, however, does not do that; on the contrary, it encourages counter values which affect the entire society. Mancuso has no doubts about consumer society being the culprit here; in fact, what he does is point directly at the heart of the problem which can explain the ethical and moral degradation of society. For Mancuso, the blame for such an abnormal situation rests categorically with what he calls "material capitalism" which seems to be the fundamental feature of consumer society (Dore, 2000, p. 58).

It has to be stressed here that - as far as Mancuso is concerned - materialist capitalism is essentially cynical, and this should account for the human being's accentuated devaluation of morality within today's society. The cynicism of the whole situation has to do with the fact that, while few elderly - to be read wise - people may not show any desire to taste the effects of materialist capitalism, youngsters will definitely sip from it in an indiscernible way. To make things even worse, the more wise people try not to appropriate the damaging values of materialist capitalism, the less youngsters are aware of its dangers. The bad news does not stop here because Mancuso takes another step further into identifying the causes of moral degeneration within our society. The ethical decay which causes everybody to desire eternal youth is heavily fueled by publicity and it is a fact for Mancuso that publicity reigns over the world of communications. Publicity tells everybody - regardless of age - that youth is desirable and a must for every human being.

This is why, having been under the immensely powerful pressure of consumer advertising, elderly people grow to appreciate youth in an unnatural way, namely; they want to be as well as behave like younger people. To use Mancuso's words, the elderly turn themselves into young consumers. Given this fact, it is very hard indeed to look for human dignity in our consumerist society, which turns the vast majority of people into individuals who want nothing more and nothing less than be, act, and look young. The consequences of this ethical degradation are saddening, to say the least, because there is no experience where experience should be, there is no wisdom where one would naturally look for it, and there is no responsibility where it should be kept as a result of life experience. For Mancuso, this is the real trap in which today's society fell without even being aware of it, this is to say that we struggle with the unnatural desire to stay young - and we selfishly accept all the consequences 
of this thought which is continuously induced in our minds by reckless advertising - without having the slightest clue that we are headed for disaster. Or, if we have, we do not want to free ourselves from its incredibly powerful grip (Mancuso, 2008, p. 240). Within such a society, one can rightly ask whether the moral agent is moral any longer, and Mancuso is obviously concerned not only with the practical reality of this troubling situation but also with its devastating consequences over people's ethical and moral awareness (Rae, 1999, pp. 68-70).

Before dealing with these consequences, however, it is necessary to understand, once more, which are the main problems of man's desire to be young. It is quite clear that nobody thinks of and nobody ponders the consequences of such a desire, and this is why Mancuso investigates the desire itself before showing what happens next with the individual and society in general. The desire to be young is based on the reality of youth and while there is nothing wrong with being young, one must be aware of what this condition actually implies. Thus, being young is being nature, and for Mancuso this happens in an exclusive way. To be sure, being young is being only nature for the simple fact that young people lack the spiritual dimension given to older people by their life experience (Thomas, 2004, pp. 45-46).

The fact of being young and consequently being only nature is alright in itself as it represents a natural condition for life and also within the life of every individual human being; the problem though arises when the fact of being young is accompanied by the desire of being young in people who have naturally and physically passed the age of youth. Mancuso's explanation is again very simple as he explains that desiring to be young despite one's aging is nothing but desiring to be only nature. There is also further clarification attached to this explanation and Mancuso goes on by saying that when people desire to stay young despite their natural aging, they deny a whole set of values. Actually, what they do is deny the superiority of culture (Ross, 1999, p. 191).

To be sure, Mancuso is convinced that people who want to be and act as if they were young go as far as denying the superior value of culture "in the noble sense of the word". The denial of culture is a real problem for the human being because it cultivates the soul and, in desiring to be young for as long as possible, people actually deny themselves the cultivation of their own soul. If the cultivation of the soul is not pursued, Mancuso explains that society exposes itself to a series of consequences which lead to deep psychological depression and a profound alteration of man's existential perception of himself especially as he awaits death. This also diminishes man's personal worth, so he no longer sees himself based on his inner value. The immediate result is the dissipation of responsibility and the degradation of man's sense of moral duty, which also leads to faulty actions, the morality of which becomes more and more problematic (Mancuso, 2008, p. 240).

Thus, man turns into an agent which is no longer moral, with devastating effects on the human being in general but also on man's respect for and pursuit of human dignity. The desire to stay young indefinitely generates, as a last consequence, the serious demeaning of humanity, which is no longer capable of achieving the basic level of human dignity by doing good. Mancuso's solution resides in man activating his moral duty towards himself and others by cultivating his soul for the benefit of others. Man must turn away from things which are totally incapable of providing nourishment for the soul and reorient himself towards the development of his own spirituality. This can be done only if man realizes that the cultivation of the soul implies the constant effort to work for something higher than he, which can turn the individual soul into an eternal spirit.

The desire to be young is the desire not to cultivate one's soul but there is also another critical issue at state. Whoever wants to stay young does not only leave his soul uncultivated and spiritually malnourished, but he also refuses to work on himself (Mancuso, 2008, p. 240).

In other words, he refuses to grow, to turn himself into a person with openness to life in all its aspects. This is, to say the least, a disturbing lack of responsibility for oneself and for 
others, which shows serious flaws in one's attitude to morality. A deficient responsibility for oneself leads to defective approaches concerning the life of other people, so whoever wants to stay young despite his aging denies himself the quality of being a moral agent. His reasoning and actions become morally impaired with serious repercussion on the very life of his fellow men and women.

\section{The social consequences of the desire to stay young: A comparison between Mancuso's Hegelian theology and Gluchman's ethics of social consequences}

In Mancuso's assessment, the first consequence of man's desire to stay young indefinitely is the alteration of his morality (Mancuso, 2008, p. 240) because, in this particular case, the materiality of the human being is not understood in spiritual terms, so the human person is incapable of accepting his own spirituality and materiality. The spirit, which is embedded in the human being at birth, should evolve into accepting the reality of aging but when the desire to stay young kicks in, this realization and acceptance of one's natural development is not understood in terms of morality and positive consequences. This has a tremendous impact upon man's moral duty to himself and others. Thus, when man wishes to stay young despite his age, he not only refuses to nourish his own life but, in doing so, he deprives others of living their lives to the fullest. Mancuso is aware of this reality because he notices that such an attitude to life leads to a profound inner sadness. Man loses his capacity to reflect on himself and others as he should, so he develops interior sadness as well as a deep sense of self-defeat (Karp, 1996, p. 171). There is a secret attached to life, Mancuso believes, and this is to reflect upon ourselves without being sad or defeated. But in order to do this, man needs a correct approach to life, which in Mancuso's thought, has to do with stepping beyond one's desire to stay young forever (Seiwert, 1998, p. 259).

This is definitely not an easy thing to do, and Mancuso is the first to acknowledge that because being willing to grow old implies a conscientious decision to work with oneself. As far as Mancuso is concerned, life gives us nothing as a gift, so working hard on one's perception about oneself is a duty which must be pursued with hard work. Man has a moral duty to himself in doing whatever necessary to nurture his soul and develop a sense of responsibility for his own life. Man's responsibility for his own life also has implications on the lives of others to the point that - if not highlighted with a view to being cultivated - the idea of the soul itself becomes superfluous. Today's people do not seek to nurture their souls because they do not have any knowledge of what the soul really is and how they should cultivate it (Mancuso, 2008, p. 240).

If there is no such awareness, if people do not know anything about the soul's existence, then this does not only have repercussion on the present state of affairs but also on what happens in future. In other words, man's decision not to take care of his soul today will impact on the lives of others in future, when they find themselves in the very same situation as people who are totally unable to accept the soul's existence and its need for cultivation. Thus, man's desire to stay young does not only modify his perception of morality but it also generates the wrong attitude towards his present and future responsibility. At the same time, man's existential perception of himself changes dramatically, which at the end of the day is nothing but a deprecation of humanity itself. All the qualities and values of humanity which are worthy of respect, and which make up human dignity as a fundamental reality for the human being, are denied by man's desire to escape his actual responsibility. In not accepting his age but searching for eternal youth, today's man displays wretched behavior which affects the worthiness and esteem of his essential dignity. The bottom line is that some human beings do not respect the dignity of others but they also ignore their own, personal dignity (Gluchman, 2006, pp. 6-7). 
One important issue here is the fact that while Mancuso seems to perceive dignity as an inborn human quality, the ethics of social consequences - as presented, for instance by Gluchman - approaches dignity as a reality which is gained by individuals, so men and women are born without it (Gluchman, 2006, p. 7). For Mancuso, though, dignity is inborn, so sadness and the feeling of self-defeat identified by him as direct consequences of man's desire to stay young are just two signs of his loss of respect for human dignity. This has in turn another consequence, namely the loss of man's desire and capacity to pursue human dignity, and this trend is not only a feature of society in general but also - if we are to accept Mancuso's evaluation - of the church in particular.

In this respect, Mancuso's mentioning of the church brings forth the second consequence of man's desire to stay young, which has a wider social impact. Because today's society is so preoccupied with the idea of maintaining youth as a constant feature of man's individual life, Mancuso seems to allege that even the church-and his reference is to the Roman-Catholic Church - has been caught up in this whirl of social and existential concerns. Today's people do not take any care whatsoever when it comes to nurturing their soul and Mancuso goes as far as saying that they do not even know what the soul is. His proof in favor of such a grim assessment is the fact that most people nowadays deny the existence of the soul - so no wonder they do not care about it - and, at the same time, they see themselves in exclusive material terms (Brown, 1999, p. 179). In other words, people perceive themselves as beings with bodies, and not with souls. Mancuso is not happy at all with the church's attitude towards the contemporary approach to anthropology and remarks that the church offers little help in supporting the existence of the soul, let alone the necessity to nurture, protect, and cultivate it (Gillis, 1999, pp. 130-131).

So, according to Mancuso, man's desire to stay young is so powerful that not even the church is keen enough to offer solutions to this crisis. To be sure, in Mancuso's view, the church does not talk about the soul and, as if this were not serious enough, it does not say anything about spirituality or prayer for that matter. The lack of an earnest discourse about soul, spirituality, and prayer is unfortunately a thrilling consequence of today's man desire to remain young, which is not countered by the church in any of its "recent formal magisterial documents". Mancuso is disturbed because, even if he does not name any document in particular, they should have been concerned with the existence of the soul and spiritual education, which is not the case because today's theologians seem to look for other hills to die on. For instance - and Mancuso is very critical here - the theologians of the church spend more time on proving that Greek philosophy contaminated Christianity with the concern for the soul and the body, so it is logical why the church does not say anything in favor of the cultivation of the soul (Mancuso, 2008, pp. 240-241).

Mancuso's intention in launching this criticism is connected with his belief that not nurturing the soul generates a damaging attitude which is demeaning of humanity in general, because the lack of effort in cultivating the soul is the other facet of the lack of interest in achieving the full potential of human dignity. At this point, Mancuso seems to come closer to the ethics of social consequences in the sense that human dignity must be cultivated in order to make it worthy and esteemed for the individual as well as for society in general. This results in the moral equality of all human beings because everybody has the duty to do whatever it takes for the benefit of others. Every human being is a moral agent and his actions must confirm this quality with respect to the best possible consequences of these actions for other human beings. Mancuso notices that the actions of today's people are degrading and, in this respect, he seems to come closer to Gluchman's conviction that the value of human actions, which confirm one's dignity, is changeable in value because human actions are not always beneficial for oneself or society for that matter (Gluchman, 2007, p. 161). 
This brings us to the third consequence of man's desire to be young, namely the fact that it spreads an illusion with devastating effects on society (Newman, 2006, pp. 185-186). The fact that what we are dealing with here is an illusion is demonstrated by Mancuso's use of two fundamental concepts: that of the "idol" and that of the "siren". Mancuso is very clear about what he has in mind by dubbing the desire to stay young an "idol"; an idol replaces the image of the real God, very much like the desire to stay young replaces man's need to nurture his soul. The desire to stay young is an idol because it sells the illusion that there is no soul, no spirituality, so the only thing left is the corporality of our natural bodies which only need things for satisfaction. Things, however, can never satiate the soul - and, just to state the obvious, Mancuso is adamant about this truth - but this whole idea that we must stay young forever hinders us from seeing what we really need in terms of our own spirituality. The desire to stay young is an idol because it distorts our true need for spiritual nourishment, cultural growth, and personal toil in modeling as well as shaping our lives towards maturity.

If man looks at the idol, he loses his own value which can be fully assessed only in the light of God's true perspective. When man entertains his desire to stay young, he loses his inner worth and eventually he loses the very essence of his human dignity. He can no longer evaluate his true value as a human being and as an integral part of humanity as a whole; he sees no meaning in his own birth into this world, so any attempt to achieve his potential will result in anything but the completion of his human dignity. With respect to the word "siren" attributed to man's desire to stay young, Mancuso is equally clear and determined: like the sirens of Greek mythology that lured sailors to destruction by their beautiful singing, the "sirens of eternal youth" lead today's people towards the path of spiritual demise by their eyecatching, soul-snatching, and mind-blowing advertisements which focus on things rather than spirituality (Lakshminarayana, 1985, p. 46). Man will never be able to fully understand himself and his place in the world - let alone grow towards his own maturity - if he continuously chooses to rely on, appreciate, and depend on things (Mancuso, 2008, pp. 240241).

The desire to stay young is, therefore, a depreciation of human life; human life is not only youth for the simple reason that it includes every developmental stage from childhood to old age. The undiscerning and exclusive appreciation of young age is an attack against human life and the dignity of human existence. Mancuso's evaluation of man's desire to stay young is therefore an attempt to reconstruct humanity by putting together the respect for spirituality as well as the pursuit of human value, culture, and dignity. His analysis also proves that man's freedom can be used in the wrong way, so the desire to stay young is also a faulty use of one's personal freedom because it causes serious damage in the lives of a whole range of individuals. This is in line with the ethics of social consequences, which deals with one's freedom and moral actions directed towards positive consequences with the clear intent to minimize the evil of every human action (Gluchman, 2007, p. 162).

Both Mancuso and Gluchman seem to be concerned with the practical character of man's morality. While Mancuso seems to be more prone to accepting the inward validity of man's morality, Gluchman tends to see morality as a "current condition" of our lives but they both suggest that we should have standards which are achievable by all human beings. In Mancuso, it seems quite clear that man has the capacity to fight the desire to stay young by cultivating his soul, and this can be done by everyone. This is not to say that the education of the soul is an easy task or that it can be done within the span of a couple of days but it is nevertheless an achievable goal. As far as Gluchman is concerned, the conviction that our actions should be inspired by achievable moral ideals which are stimulating for the actions of most people with the purpose of having beneficial, positive consequences for today's society (Gluchman, 2003, p. 18). 
If this expectation is not met, we come across the fourth consequence of man's desire to stay young, which is the deterioration of man's existential perception of himself. Thus, if man collapses before the idol and the sirens of eternal youth, he will have a whole range of expectations which are not meant to fulfill the spiritual dimension of his life, so - to use Mancuso's phrase - he will enter the "vortex of the darkest depression" (Mancuso, 2008, p. 241). This happens because, while man nurtures the desire to stay young no matter what, his body will inevitably grow old and show clear signs of aging but this is only part of the problem. Man's desire to stay young is not countered only by the fact that his body ages which is more and more visible despite man's efforts to temper down the process of leaving behind his own youth - but also by the realization that he gets closer to death. Aging and death leave distinct marks on the human body, and Mancuso is not afraid of highlighting them because man's failure to see his existence in the light of his end will inevitably lead to a false appreciation of himself. Actually, man will see himself permanently as a young body despite the fact that the signs of physical decay and death impose their presence on man's body. Left without spirituality, namely without an educated and cultivated soul, man will eventually lose his desire to stay young but when he realizes that he is heading towards death, his existential dimension will be grabbed by depression (Newman \& Newman, 2009, pp. 518-519).

Mancuso is keen to underline this reality because while every human individual has to face death on his own, the realization of the vicinity of death and the subsequent depression can become a social phenomenon if the desire to stay young forever is not replaced by the effort to educate the soul. What Mancuso seems to imply here is that one remedy to deal with death is understand that the body is inextricably linked with time, while the soul is the only human reality which has the chance to transcend it. He explains that the body is "made of time", which means that it is actually connected with time, and this is the reason why the body eventually dies (Patterson, 2005, p. 92).

The body and its own demise are connected through the reality of time, and the necessity for man to understand this fact is compulsory. Man must also accept that even the soul is linked with time, and this connection should not be underestimated. To use Mancuso's rendering, the human soul is "interwoven" with time but despite this, the soul also has the possibility to go beyond time. He goes on with his explanation by saying that the soul has the capacity to reach eternity and also to become eternal. On the other hand, the eternity of the soul cannot be achieved without education, and the education of the soul means cultivating the desire to do good. The soul must die to the physicality of time; in other words, the soul must liberate itself from the clutches of time because this is the only chance to rid itself of passions - including the desire to stay young forever - and death. The acceptance of death without sadness and depression is possible only through the cultivation of the soul, and this seems to be the only possibility which Mancuso envisages for straightening man's existential expectations. At the same time, the education of the soul is also the only medicine - at least in Mancuso's mind - which can cure the social consequences of the individual's sadness and depression. The education of the soul should therefore bring about the restoration of human life, human dignity, and eventually, of humanity as a whole (Mancuso, 2008, p. 241).

The education of the soul cannot be made without the correct use of one's rationality, consciousness, and will, so in this particular respect Mancuso comes closer once again to the ethics of social consequences which sees the development of these three faculties as the foundation for the recognition of dignity within the human being. When used correctly, human rationality, consciousness, and will become the means to educate and enrich one's soul and life, as also proved by Gluchman who compares human life with a vessel which is filled with various items, and it is our decision that we pour into it. Mancuso decries the fact that today's people pour the garbage of so-called eternal youth into the vessel of life, which 
Gluchman admits that the value of life is dependent of where human beings decide to pour valuable, respectful, and esteemed actions into it (Gluchman, 2006, pp. 10-11).

The fifth and last consequence of man's desire to stay young is the fact that man's soul will remain in a state of constant impairment, which will hinder it from working for something higher than itself. The human soul needs experience and wisdom to fulfill its true possibilities; otherwise, the soul is nothing but a surrogate with no other concerns than material and physical things (Hagen, 2004, p. 106). Mancuso believes that today's society has certain knowledge of what the soul should be for the simple reason that there is no humanity without the soul. The problem is that today's people are so captivated by the desire to stay young that they perceive the soul only as psyche (McCleary, 2004, p. 334).

According to Mancuso, the psyche is the soul in its lowest, most basic form, the soul as character, the soul in its natural and psychical state. However, in order for the soul to be cultivated, man must break the barrier of psychical dimension which allows the soul to work for a higher purpose. Left on its own, the human soul will always be preoccupied with itself; education though will provide it with the chance to avoid being devoured by time, and this is possible only when the soul works for others. In Mancuso, the destiny of the human soul is to become eternal, but eternity is secured only if the soul dies to its own psyche and, in doing so, it becomes spirit (Mancuso, 2008, p. 241).

The journey from soul to spirit, however, implies the soul's death to its own passions if the human being really wants not to be left at the mercy of death. Thus, the death of the soul to itself and its subsequent transformation - through education and culture - into spirit is the only way to destroy the idol and the sirens of man's desire to stay young. The resurgence of the soul as spirit will therefore provide us with the restoration of humanity, so that the human being should be fully aware of its need to respect and pursue its dignity. The recapturing of the true value of human dignity though is possible - in Mancuso's thought - when the soul strives to do good beyond its own profit to the benefit of others. This implies a dramatic change of morality, so man should educate his soul into acquiring the true meaning of responsibility, duty, tolerance, and profitable action for himself and others. To be sure, this has nothing to do with the traditional doctrine of sin, which Mancuso repudiates by radically reinterpreting it, and in doing so he agrees with the ethics of social consequences as promoted by Gluchman. Sin as guilt and the failure to live according to God's claims each moment is not desirable - either for Mancuso or for Gluchman - because such an understanding is oppressive for Mancuso (Mancuso, 2008, p. 26) and utopian for Gluchman (Gluchman, 2003, p. 17).

However, both Mancuso and Gluchman share the conviction that the social consequences of human actions must be directed towards their most positive result. Man must be aware that his actions have consequences and the positivity of these consequences should prevail. We must be willing to maximize the positive results of our actions as proof that our dignity was informed by principles which attempt to find solutions to the problems of today's world (Gluchman, 2003, pp. 16-19).

\section{Conclusion}

Mancuso begins his argumentation from the reality of youth, which is defined as a crude state of man's natural corporality; in turn, corporality is defined not only in physical but also spiritual terms but the idea of the spirit in Mancuso, which he borrows from Hegel, is defined in material terms. Inspired by Hegel, Mancuso believes that the materiality of the human being is profoundly spiritual while the spiritualty of the same human being is deeply material. Given the material feature of the spirit, however, the spirit is supposed to evolve, develop, and acquire new meanings of life and existence, so when the human being evolves materially in 
the sense that it ages while it seems to remain young in spirit in the sense that it refuses to accept aging then the human being, according to Mancuso, has a very serious problem. In Mancuso, young age is marked by cultural and spiritual underdevelopment, which is in need of growth and maturity through life experience.

The latter is the only aspect that can turn youth into an age of wisdom but naturally wisdom is associated more with older age. Mancuso's problem is neither with youth nor with older age; what he does see as a problem, however, is the fact that in today's society, older people - whose life should be characterized by wisdom - have been lured into believing that the ideal of life is younger age, so they develop a specific desire to stay young indefinitely despite their natural aging. Mancuso's concern for a thorough presentation of young people and especially of their mentality - is connected with the fact that today's desire to stay young shared by most of our contemporaries despite their aging is based on the portrayal of youth as the human ideal by means of aggressive advertising. This is why a correct presentation of the features of young age will consequently present us with a clear picture of the morality, expectations, and desires of today's society. People turn into individuals who desire youth without realizing the immaturity associated with it and they strive to keep it, despite the fact that such a decision impairs their capacity to see life as it unfolds within the reality of the world. This turns both younger and older people into victims who seek to lead an immature life of decadence and abnormal expectations. As people grow old, they no longer want to look for wisdom, which can provide them with a clear picture of their own value as a sign of healthy morality, but they rather indulge in the lies of advertising that will fuel their existence with false hopes and eventually will push them into sadness and despair.

Having explored the characteristics of young people which help us build an image of the entire society due to contemporary man's fascination with youth, Mancuso identifies five social consequences of man's desire to stay young in spite of natural aging. First, he realizes that man's refusal to grow old despite his natural coming closer to death leads to an alteration of morality. Because of the desire to remain young, man refuses to nurture his soul spiritually and culturally, and in doing so he also convinces himself that the reality of his own soul is overrated. Second, this perspective seems to have permeated even within the church - which, in Mancuso, is the Roman-Catholic Church - which reportedly issued a series of documents which avoid the issue of the cultivation and nourishment of the soul. This promotes a demeaning approach to human life which leads to the pursuit of human dignity by man's active implication in doing good. Third, man's desire to remain young sells an illusion which lies in everybody's face.

By using terms like "idol" and "siren", Mancuso shows that this desire hinders people from seeing life as it is and those affected by it tend to be fully dependent on things, and not on spirituality. As Mancuso is convinced that things will never be able to nurture the soul, he criticizes today's society for allowing itself to fall prey to a set of lies which tread on human values and dignity. Fourth, the existential perception of man about himself is seriously damaged by the desire to stay young indefinitely, so today's people are most likely to suffer from severe depression in the face of death. Life is no longer appreciated with all its aspects death included - so the vicinity of death produces despair in those whose soul was not cultivated and educated to accept the end of life in a spiritual way. Fifth, and last, the desire for eternal youth convinces people not to work hard for realities higher than themselves. Thus, individuals are no longer concerned with helping their fellow men and women, so doing good for the benefit of others is not part of what the soul becomes when left without spiritual education. Without education, the soul is devoid of wisdom, and this lack of wisdom will keep the soul away from the possibility of reaching eternity. The only option for the soul to become eternal is to become spirit but this requires a thorough reassessment of morality based on the cultivated promotion of human dignity and the benevolent adherence to perform good, moral 
actions. The soul must die to itself and its passions - which include the desire to stay young in an attempt to enhance humanity by respecting and pursuing human dignity.

It is here that Mancuso's Hegelian thought comes very close to Vasil Gluchman's ethics of social consequences. Like Gluchman, Mancuso sees the human being as characterized by humanity which should be in constant pursuit of human dignity; in turn, human dignity can never be fully achieved if the human being refuses to accept aging as a natural part of its materiality and clings to the idea of staying young. The acceptance of aging in Mancuso appears to be an attempt to preserve not only human dignity but also human life, and especially the fullness of human life, which turns men and women into moral agents as Gluchman points out. Moral reasoning and moral action, so characteristic to Gluchman's ethics of social consequences, are vividly present in Mancuso's Hegelian theology because the latter's criticism of man's desire to stay young against the natural reality of aging and death is an attempt to steer man's behavior in the direction of right actions and moral actions to the point that man accepts his materiality and finiteness as part of his innermost spirituality.

Thus, like Gluchman's ethics of social consequences, Mancuso's Hegelian theology concentrates on the prevalence of positive consequences which help humanity accept its materiality, naturality, and finiteness in a dignified, spiritual, and positive way. Moreover, instead of promoting an unnatural and unspiritual focus on the desire to stay young, Mancuso appears to defend the idea of moral duty which, very much like in Gluchman, tends to teach contemporary men and women to shows compassion, acceptance, and responsibility not only towards elderly people but also towards younger ones who are deluded into believing that staying young can somehow elevate their self esteem and self worth.

Corneliu C. Simuţ, is Professor of Historical and Systematic Theology at Emanuel University of Oradea and Associate Research Fellow at the University of Pretoria, where he currently works as Postdoctoral Researcher on the idea of ecodomy in Romanian Eastern Orthodox nationalistic rhetoric as well as in indigenous African religions under the supervision of Professor Johan Buitendag. He is the author of numerous articles and books, the latest of which is F. C. Baur's Synthesis of Böhme and Hegel. Redefining Christian Theology as a Gnostic Philosophy of Religion (Leiden: Brill, 2015).

\section{Corresponding author:}

Corneliu C. Simuț, Emanuel University of Oradea, Str. Nufarului Nr. 87, 410597 Oradea, Bihor, Romania

email: corneliu.simut@emanuel.ro

\section{References}

BOOTH, D. A. (1994): Psychology of Nutrition. London: Taylor \& Francis.

BROWN, P. J. (1999): Canon 17 CIC 1983 and the Hermeneutical Principles of Bernard Lonergan. Roma: Editrice Pontificia Università Gregoriana.

DORE, R. (2000): Stock Market Capitalism: Welfare Capitalism: Japan and Germany versus the Anglo-Saxons. Oxford: Oxford University Press.

FRIEL, J. \& FRIEL L. (1988): Adult Children: The Secrets of Dysfunctional Families. Deerfield Beach, FL: Health Communications.

GILLIS, C. (1999): Roman Catholicism in America. New York, NY: Columbia University Press.

GLUCHMAN, V. (2006): A Concept of Human Dignity. In: Hekmat va Falsafeh [Wisdom and Philosophy], 1(4), pp. 5-14. 
GLUCHMAN, V. (2003): Human Being and Morality in Ethics of Social Consequences. Lewiston, Queenston, Lampeter: The Edwin Mellen Press.

GLUCHMAN, V. (2007): Human Dignity and Non-Utilitarian Consequentialist 'Ethics of Social Consequences'. In: H. Tepe \& S. Voss (eds.): The Proceedings of the Twenty-First World Congress of Philosophy, Volume 1: Ethics. Ankara: The Philosophical Society of Turkey, pp. 159-165.

HAGEN, J. (2004): The Power of Love: The Return to the Father's House. Coral Springs, FL: Llumina Press.

KARP, D. A. (1996): Speaking of Sadness: Depression, Disconnection, and the Meanings of Illness. Oxford: Oxford University Press.

KEREM, Y. (1999): The Europeanization of the Sephardic Community of Salonika. In: Y. K. Stillman \& N. A. Stillman (eds.): From Iberia to Diaspora: Studies in Sephardic History and Culture. Leiden: Koninklijke Brill, pp. 58-74.

LAKSHMINARAYANA, H. D. (1985): College Youth Challenge and Response. Delhi: Mittal Publications.

MANCUSO, V. (2008): Rifondazione della fede. Milano: Mondadori.

MCCLEARY, R. (2004): A Special Illumination: Authority, Inspiration, and Heresy in Gay Spirituality. London: Equinox Publishing.

NEWMAN, B. M. \& NEWMAN, P. R. (2009): Development through Life: A Psychological Approach, 10th edition. Belmont, CA: Wadsworth Cengage Learning.

NEWMAN, D. M. (2006): Sociology: Exploring the Architecture of Everyday Life, 6th edition. Thousand Oaks, CA: Pine Forge Press/Sage Publications.

PASCAL, B. (1995): Pensées and Other Writings. Oxford: Oxford University Press.

PATTERSON, D. (2005): Hebrew Language and Jewish Thought. Abingdon: RoutledgeCurzon/Taylor \& Francis.

PRYKE, R. (2006): Weight Matters for Young People: A Complete Guide to Weight, Eating, and Fitness. Abingdon: Radcliffe Publishing.

RAE, S. B. (2000): Moral Choices: An Introduction to Ethics, 2nd edition. Grand Rapids, MI: Zondervan.

RAE, S. B. \& COX, P. M. (1999): Bioethics: A Christian Approach in a Pluralistic Age. Grand Rapids, MI: Eerdmans.

ROSS, S. D. (1999): The Gift of Kinds: The Good in Abundance: An Ethic of the Earth. Albany, NY: State University of New York Press.

STETSON, B. (1998): Human Dignity and Contemporary Liberalism. Westport, CT: Praeger Publishers.

SEIWERT, H. (1998): Health and Salvation in Early Daoism: On the Anthropology and Cosmology of the Taiping Jing. In: A. I. Baumgarten, J. Assmann \& G. G. Stroumsa (eds.): Self, Soul, and Body in Religious Experience. Leiden: Brill, pp. 256-275.

SIMUT, C. (2011): Essentials of Catholic Radicalism: An Introduction to the Lay Theology of Vito Mancuso. Frankfurt am Main: Peter Lang.

STONE, J. (2001): Behavioral Discrepancies and the Role of Construal Processes in Cognitive Dissonance. In: G. B. Moskowitz (ed.): Cognitive Social Psychology: The Princeton Symposium on the Legacy and Future of Social Cognition. Mahwah, NJ: Lawrence Erlbaum Associates, pp. 41-58.

THOMAS, W. H. (2004): What Are Old People For? How Elders Will Save the World. Acton, MA: VanderWyk \& Burnham.

TURIEL, E. (2002): The Culture of Morality: Social Development, Context, and Conflict. Cambridge: Cambridge University Press. 